\title{
Asosiasi Lalat Buah (Bactrocera spp.) (Diptera : Tephritidae) dan Parasitoidnya pada Tanaman Jambu Biji Kristal (Psidium guajava L.) yang Dibudidayakan di Bali
}

\section{WAYAN DEDI ADNYANA*), NI NENGAH DARMIATI, DAN DWI WIDANINGSIH}

\author{
Program Studi Agroekoteknologi, Fakultas Pertanian Universitas Udayana \\ Jln. P.B. Sudirman Denpasar 80232 Bali \\ ${ }^{*}$ E-mail: dediadnyana86@gmail.com
}

\begin{abstract}
Association of Fruit Flies (Bactrocera spp.) (Diptera: Tephritidae) and Their Parasitoid on Guava (Psidium guajava L.) Cultivated in Bali. The study on the association of fruit flies (Bactrocera spp.) (Diptera: Tephritidae) and their parasitoid on guava (Psidium guajava L.) cultivated in Bali was conduted in order to know the abundance, attacks percentage and the species of parasitoid associated on guava, cultivated in Bali. The sampling was done intentionally by taking attacked fruit in Musi Village, Buleleng Regency; Pelaga Village, Badung Regency; and Tiga Village, Bangli Regency. The results showed that 3 species of fruit flies were found, namely B. carambolae, B. papayae and B. albistrigata. The percentage and number of adult insect emergence in Musi Village were $B$. papayae (50.87\% ; 2772 imago), B. carambolae (35.18\% ; 1803 imago) and B. albistrigata $(13.94 \%$; 741 imago). In Pelaga Village B. carambolae $(61.31 \%$; 2864 imago) dominates and $B$. papayae only $38.69 \%$ and 1801 imago. B. carambolae is also found dominant in Tiga Village (59.08\% ; 2303 imago) and B. papayae only $40.92 \%$ and 1603 imago. Percentage of damage to guava is $24.27 \%$ on average. There are three species of parasitoids found that are associated with fruit flies on guava in Bali, namely Fopius arisanus, Diachasmimorpha sp. and Opius sp. The average parasitic rate is 6.76\%. The highest parasitic rate is in Musi Village, Buleleng while the lowest is in Tiga Village, Bangli.
\end{abstract}

Keywords: Abundance, Attacks Percentage, Fruit Flies, Parasitoid, Guava

\section{PENDAHULUAN}

Indonesia merupakan negara agraris dan negara tropis yang kaya tanaman hortikultura. Hortikultura merupakan salah satu andalan masyarakat Indonesia sebagai sumber pangan dan pendapatan. Salah satu komoditas hortikultura yang berpeluang untuk dikembangkan adalah jambu biji (Psidium guajava L.). Jambu biji memiliki rasa yang manis dan dikenal sejak lama oleh masyarakat Indonesia. Selain itu kandungan gizi yang cukup tinggi membuat buah itu disukai oleh masyarakat. Menurut Prihatman, (2000) buah muda jambu biji dan daunnya 
I WAYAN DEDI ADNYANA. et al. Asosiasi Lalat Buah (Bactrocera spp.) (Diptera : Tephritidae)...

dapat digunakan untuk mengobati diare, Kecamatan Gerokgak, Kabupaten Buleleng sedangkan kayu pohon jambu biji yang (Rai et al., 2016). Pada tahun 2013 produksi cukup keras dapat digunakan untuk bahan jambu biji di Provinsi Bali mencapai 2.986 perabot rumah tangga. Kandungan buah ton (Dinas Pertanian Provinsi Bali, 2014). jambu biji (dalam 100 gr), yaitu kalori $49 \mathrm{kca}$ Namun dalam perkembangannya, budidaya 1; vitamin A 25 SI ; vitamin B1 0,02 mg; tanaman jambu biji menghadapi beberapa vitamin C $87 \mathrm{mg}$; kalsium $14 \mathrm{mg}$; kendala yang berasal dari faktor iklim dan karbohidrat 12,2 gr ; fosfor $28 \mathrm{mg}$; besi 1,1 OPT (Organisme Pengganggu Tanaman). $\mathrm{mg}$; protein $0,9 \mathrm{mg}$; lemak $0,3 \mathrm{gr}$; dan air 86 Salah satu OPT yang dapat merusak jambu gr.

Tanaman jambu biji memiliki beberapa varietas diantaranya jambu kristal, jambu susu, jambu bangkok, jambu sukun, jambu pir/pear, jambu merah getas, jambu Australia dan jambu biji lokal (Rai et al., 2016). Jambu biji varietas kristal atau lebih dikenal sebagai jambu kristal merupakan jambu biji varietas baru yang mulai dibudidayakan. Jambu kristal masuk ke Indonesia melalui Misi Teknik Taiwan (Taiwan Technical Mission in Indonesia) pada tahun 1998. Jambu biji tersebut disebut kristal karena warna daging buahnya putih agak bening dan secara kasat mata bentuk jambu kristal juga berlekuk-lekuk bulat tidak sempurna menyerupai bentuk kristal (Trubus, 2014).

Saat ini dibeberapa tempat di Bali sudah dikembangkan jambu biji secara komersial sehingga telah menjadi sentra produksi jambu biji, yaitu di Kecamatan Petang, Kabupaten Badung dan di biji adalah lalat buah.

Buah jambu biji yang bergejala akibat serangan lalat buah biasanya ditandai oleh adanya lubang kecil di bagian permukaan kulit buah yang hampir masak. Kerusakan buah disebabkan oleh aktivitas larva memakan daging buah yang memicu terjadinya pembusukan. Apabila pembusukan tersebut meluas seiring dengan masaknya buah, maka akhirnya buah jatuh ke tanah. Kerugian hasil panen buah yang disebabkan oleh serangan lalat buah mencapai 30-60\% dan dapat meningkat hingga 80\% apabila tidak dilakukan upaya pengendalian hama (Sodiq, 2004).

Ada beberapa jenis lalat buah yang teridentifikasi menyerang tanaman jambu biji, yaitu lalat buah jenis Bactrocera umbrosus, B. carambolae, B. papayae dan B. albistrigata (Hasyim et al., 2008). Menurut White dan Hancock (1997) spesies lalat buah yang dominan menyerang tanaman 
jambu biji kristal adalah $B$. carambolae dan B. papayae.

Sebagai bagian dari ekosistem, populasi lalat buah di alam dikendalikan oleh musuh alami. Salah satu musuh alami lalat buah adalah parasitoid. Parasitoid yang berasal dari famili Braconidae, yaitu Fopius sp. dan Biosteres sp. merupakan parasitoid yang berasosiasi dengan lalat buah (Siwi et al., 2006).

Berdasarkan uraian di atas maka perlu dilakukan penelitian untuk mendapatkan informasi tentang kelimpahan, persentase serangan lalat buah dan tingkat parasitisasi parasitoidnya pada tanaman jambu biji kristal yang dibudidayakan di Bali.

\section{METODE PENELITIAN}

\section{Tempat dan Waktu Penelitian}

Penelitian lapang dilaksanakan di sentra tanaman jambu biji kristal Provinsi Bali yaitu Desa Musi Kecamatan Grokgak Kabupaten Buleleng (16 m dpl), Desa Pelaga Kecamatan Petang Kabupaten Badung (1167 m dpl) dan Desa Tiga Kecamatan Susut Kabupaten Bangli (568 m dpl). Penelitian laboratorium dilaksanakan di Laboratorium Pengelolaan Terpadau Hama dan Penyakit Tumbuhan Fakultas Pertanian Universitas Udayana dan Balai Karantina Pertanian Kelas I Denpasar. Penelitian ini dilaksanakan sejak bulan Februari sampai bulan April 2019.

\section{Alat dan Bahan}

Alat yang digunakan dalam penelitian ini adalah mikroskop stereo trinokuler dengan bantuan kamera merek Optilab, cawan Petri, pinset, kuas, gunting, kain kasa, karet gelang, plastik bening dan botol plastik transparan. Bahan yang digunakan dalam penelitian ini adalah tanah sebagai media perkembangan pupa lalat buah dan sampel buah jambu biji yang terserang lalat buah.

\section{Pelaksanaan Penelitian}

\section{Metode Pengambilan Sampel Buah Terserang}

Setiap lahan penelitian memiliki luas \pm 50 are. Penentuan titik sampel dilakukan dengan metode diagonal. Pada lahan penelitian dibentuk 5 unit sampel dengan luas 9 × 9 meter, di masing-masing unit sampel terdapat 9 tanaman yang diamati, sehingga total pohon jambu biji yang di sampling dalam satu lahan penelitian adalah 45 pohon. Pada setiap unit sampel, buah terserang diambil secara purposive yaitu buah yang sudah jatuh maupun yang masih di atas pohon. Dalam satu unit sampel diambil sebanyak 15 buah, sehingga diperoleh total buah yang diambil dalam satu lahan adalah 
I WAYAN DEDI ADNYANA. et al. Asosiasi Lalat Buah (Bactrocera spp.) (Diptera : Tephritidae)...

75 buah. Buah jambu kristal yang digunakan sebagai sampel adalah buah yang menunjukkan adanya gejala serangan lalat buah.

\section{Metode Pemeliharaan Lalat Buah}

Sampel buah jambu biji kristal terserang lalat buah diletakkan di wadah pemeliharaan yang terbuat dari botol plastik transparan dengan ukuran tinggi $23 \mathrm{~cm}$ dan diameter $8,5 \mathrm{~cm}$ berisikan tanah setinggi 10 $\mathrm{cm}$, untuk media perkembangan lalat buah pada fase pupa. Pada bagian atas botol plastik ditutup dengan kain kasa dan diikat karet gelang sebagai ventilasi udara. Botol kemudian diberi label menurut waktu, tempat dan nomer buah. Satu wadah pemeliharaan berisikan satu buah jambu biji kristal terserang lalat buah.

\section{Identifikasi Lalat Buah dan Parasitoid}

Identifikasi dilakukan berdasarkan ciri morfologi imago lalat buah menurut

Drew (2011), Pedoman identifikasi lalat buah dari buku Training Workshop On Fruit Flies Of Indonesia : Their Identification and Pest Status Kerjasama Kementrian Pertanian RI dengan Australia (2006) dan menggunakan perbandingan dengan spesimen lalat buah di Balai

Karantina Kelas I Denpasar. Parasitoid diidentifikasi menggunakan kunci determinasi dari Sharkey (1992) dan Carmichael et al. (2005). Indeks kelimpahan relatif dihitung dengan persamaan yang diadopsi dari Krebs (1989), sedangkan rumus tingkat parasititasi dihitung dengan rumus dari Buchori et al. (2010) :

1. Kelimpahan spesies :

$$
\text { Kelimpahan }(\mathrm{K})=\frac{\text { Jumlah spesies yang ditemukan dilokasi } \mathrm{x}}{\text { Jumlah keseluruhan spesies yang terdapat di lokasi } \mathrm{x}} \times 100
$$

2. Tingkat parasitisasi dihitung dengan rumus sebagai berikut :

$$
\mathrm{P}=\frac{\sum \text { Imago parasitoid A }}{\sum \text { Imago lalat buah }+\sum \text { Imago Parasitoid A }} \times 100 \%
$$

Keterangan:

$\mathrm{P}$

Parasitoid A

Imago lalat buah

\footnotetext{
$=$ Tingkat parasitisasi $(\%)$

= Jumlah imago salah satu parasitoid yang muncul

= Jumlah total imago lalat buah yang muncul dari pupa yang tidak terparasitisasi
} 
Pengamatan Serangan Lalat Buah pada Tanaman Jambu Biji Kristal

Metode pengamatan menggunakan unit sampel yang tersebar secara diagonal pada lahan seluas 50 are. Variabel yang diamati adalah jumlah buah awal, jumlah buah terserang per minggu dan jumlah buah sehat. Pengamatan dilakukan selama lima minggu. Berikut ini adalah rumus untuk menghitung persentase serangan menurut Hidayat (1982)

Persentase serangan $=$

$$
\frac{\text { Jumlah buah terserang }}{\text { Jumlah buah sehat }} \times 100 \%
$$

\section{Analisis Data}

Data yang diperoleh dianalisis secara deskriptif, informasi yang diperoleh kemudian diinterpretasikan berdasarkan data dan catatan yang diperoleh selama penelitian dan studi literatur yang menunjang.

\section{HASIL DAN PEMBAHASAN}

\section{Hasil Identifikasi Lalat Buah}

Hasil penelitian menunjukkan bahwa terdapat tiga spesies lalat buah yang menyerang jambu biji kristal di Bali yaitu Bactrocera carambolae, B. papayae dan B. albistrigata.

Tubuh spesies B. carambolae (Gambar 1) berukuran sedang yaitu 3,5-4,5 $\mathrm{mm}$. Bagian wajah terdapat sepasang bintik hitam oval berukuran sedang. B. carambolae memiliki sayap dengan pita kosta tipis berwarna hitam kemerahan melewati $\mathrm{R} 2+3$ dan sedikit melebar di bagian ujung dari $\mathrm{R} 2+3$ yang juga melewati ujung dari $\mathrm{R} 4+5$ dan terdapat garis anal sempit yang beraneka ragam. Pada bagian toraks terdapat lobus postpronotal berwarna kuning, skutum hitam pekat dengan coklat di belakang lateral postutural vittae, terdapat dua pita kuning (lateral postutural vittae) yang lebar berbentuk pararel melewati rambut intra alar dan scutelum berwarna kuning. Abdomen terga III-V berwarna coklat oranye dengan pola " $T$ " yang jelas dengan garis hitam tipis melintang pada anterior margin dari tergum III dan melebar menutupi sisi bagian samping, garis hitam medial longitudinal hitam berukuran sedang melewati ketiga tergum, sudut anterolateral corners pada tergum IV berwarna hitam merah hingga hitam dan berbentuk persegi empat, sudut anterolateral corners pada tergum V berwarna coklat merah, sepasang bintik oval berwarna coklat oranye mengkilap pada tergum V. Pada bagian tungkai, femur berwarna kusam dengan spot hitam berbentuk bulat panjang dan tibia berwarna coklat pudar.

Tubuh spesies B. papaya (Gambar 2) berukuran sedang yaitu 3,5-4,5 mm. Hampir 
I WAYAN DEDI ADNYANA. et al. Asosiasi Lalat Buah (Bactrocera spp.) (Diptera : Tephritidae)...

seluruh bagian kaput berwarna kuning berwarna hitam coklat dan bagian pretarsus kecokelatan dan terdapat sepasang titik hitam (facial spot) berbentuk oval berukuran sedang. Sayap dengan pita kostal tipis berwarna hitam coklat tepat pada $\mathrm{R} 2+3$ atau hanya melewati cabang $\mathrm{R} 2+3$, adanya tumpang tindih pembuluh di $\mathrm{R} 2+3$ menyebabkan pita kostal memudar dan menyempit kemudian pita kostal kembali melebar dan terbentuk seperti kail ikan kecil di sekitar ujung $\mathrm{R} 4+5$. Toraks dengan postpronotal lobe berwarna kuning, skutum hitam, pita kuning (lateral postutural vittae) membentuk pararel berakhir tepat atau dibelakang intra alar dan skutelum berwarna kuning. Abdomen tergum III-V berwarna coklat oranye dengan pola " $\mathrm{T}$ " yang jelas dengan garis hitam tipis melintang pada anterior margin tergum III yang sedikit melebar disisi lateral, medial longitudinal berwarna hitam berukuran sedang melewati ketiga tergum, anterolatera corners berwarna hitam pada tergum IV dan V berbentuk segitiga, ada sepasang spot coklat oranye mengkilap pada tergum V. Pada bagian kaki femur umumnya berwarna kuning coklat, tibia depan dan belakang berwarna hitam kecoklatan, bagian pangkal tibia tengah

berwarna kuning coklat.

Tubuh spesies B. albistrigata (Gambar 3) berukuran sedang sekitar 3,5-4,5 mm. Bagian wajah terdapat titik hitam berbentuk oval. Bagian torak, skutum didominasi warna hitam, terdapat garis medial longitudinal berwarna keputih-putihan, terdapat rambut pada anterior supra alar dan 2 rambut pada scutum, postpronotal lobe berwarna kuning, lateral postsutural vittae bertipe meruncing tidak begitu lebar (sedang) dan berakhir sebelum intra alar. Sayap dengan pola gambaran spesifik, hanya dengan pita hitam melintang mencapai $\mathrm{rm}$ dan $d m$ dan pita hitam pada garis anal, pita kostal kedua penuh dengan bulu-bulu halus, pita kostal melewati R2+3. Abdomen terga III-V berwarna oranye kecoklatan dengan medial longitudinal yang melebar dari terga III hingga terga $\mathrm{V}$ dan pola hitam yang lebar di sisi lateral. Tungkai didominasi berwarna kuning pucat. 

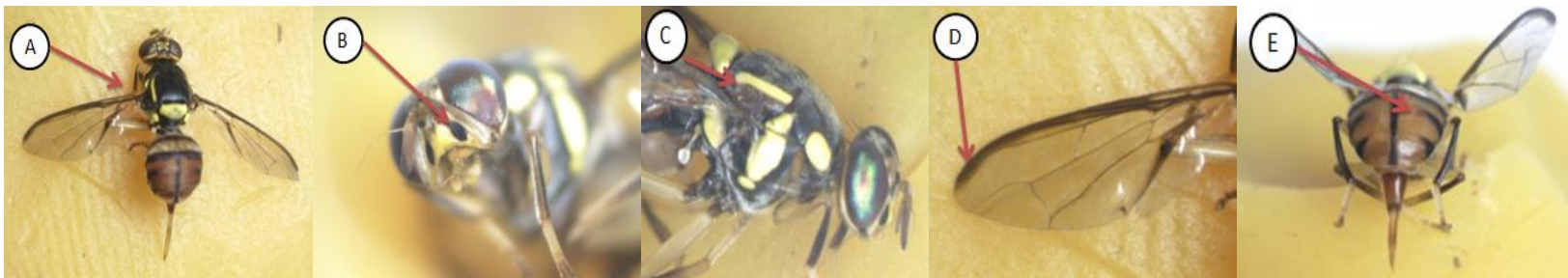

Gambar 1. Morfologi B. carambolae Keterangan : (A) Spesies B. carambolae secara utuh (B) Caput : terdapat spot hitam berbentuk oval (C) Toraks : terdapat pita kuning berbentuk pararel melewati rambut intra alar (D) Sayap : kosta tipis berwarna hitam melewati $\mathrm{R} 2+3$ dan sedikit melebar di bagian ujung dari $\mathrm{R} 2+3$ yang juga melewati ujung dari R4+5 (E) Abdomen : terdapat pola hitam berbentuk segiempat pada tergum IV
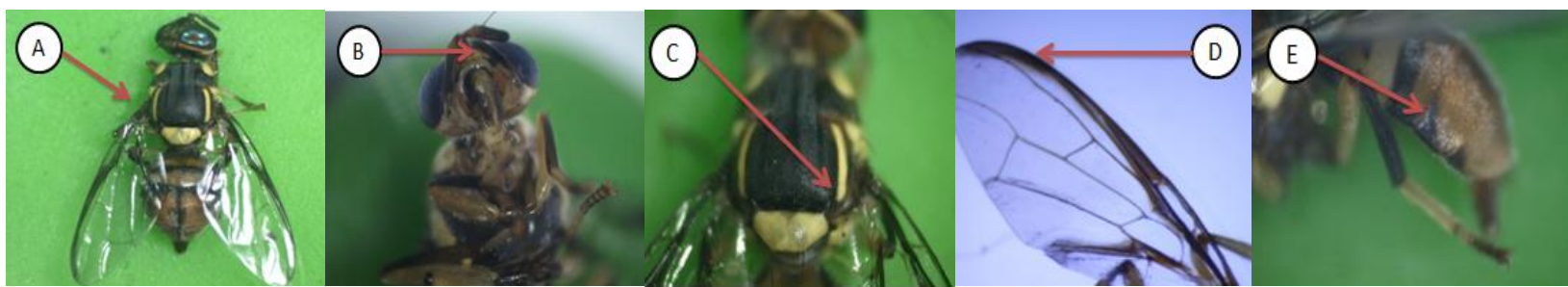

Gambar 2. Morfologi B. papayae Keterangan : (A) Spesies B. papayae secara utuh (B) Caput : terdapat spot hitam besar berbentuk oval pada muka (C) Torak : pita kuning pararel berakhir tepat atau dibelakang intra alar (D) Sayap pita kostal seperti kail ikan kecil di sekitar ujung R 4+5 (E) Abdomen : abdomen berwarna coklat oranye dengan pola " $\mathrm{T}$ " yang tipis dan terdapat pola hitam berbentuk segitiga pada tergum IV-V
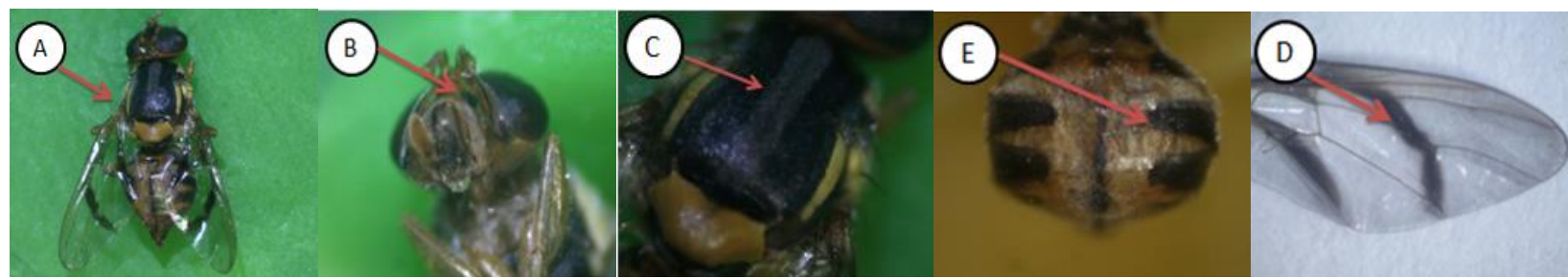

Gambar 3. Morfologi B. albistrigata Keterangan : (A) Spesies B. albistrigata secara utuh (B) Caput : dengan facial spot hitam berbentuk oval (C) Torak : terdapat garis medial longitudinal berwarna keputih-putihan (D) Sayap : dengan pita hitam melintang (E) Abdomen : medial longitudinal yang melebar dari terga III hingga terga $\mathrm{V}$ dan pola hitam yang lebar di sisi lateral

\section{Kelimpahan Spesies Lalat Buah}

Kelimpahan spesies lalat buah di Desa Musi (16 m dpl) didominasi oleh B. papayae yaitu sebesar $(50,87 \% ; 2772$ imago $), B$. carambolae $(35,18 \%$; 1803 imago) dan $B$. lokasi pengamatan Desa Tiga (568 m dpl ) albistrigata $(13,94 \% ; 741$ imago). B. carambolae mendominasi di Desa Plaga (1167 m dpl) sebesar $(61,31 \%$; 2864 imago) dan B. papayae sebesar $(38,69 \% ; 1801$ imago). B. carambolae juga mendominasi di 
I WAYAN DEDI ADNYANA. et al. Asosiasi Lalat Buah (Bactrocera spp.) (Diptera : Tephritidae)...

sebesar $(59,08 \%$; 2303 imago $)$ dan $B$. terdapat tanaman inang lain di sekitar lokasi papayae (40,92\% ; 1603 imago) (Gambar 4). pengamatan seperti mangga, jambu air, Berdasarkan hasil tersebut, populasi nangka dan yang lainnya. Pengamatan di B. papayae ditemukan lebih banyak pada lokasi yang lainnya tidak ditemukan $B$. dataran yang lebih rendah $(15 \mathrm{~m} \mathrm{dpl})$, albistrigata diduga karena tidak adanya sedangkan B. carambolae pada ketinggian tanaman inang lainnya di sekitar tempat tempat yang lebih tinggi (568-1167 m dpl). pengamatan. Menurut Maramis (2005), Hal ini dapat disebabkan karena perbedaan besarnya populasi di alam maupun keberadaan tanaman inang utama. Menurut kelimpahan populasi serangga pada suatu White dan Hancock (1997) tanaman inang habitat ditentukan oleh adanya utama B. papayae adalah papaya dan keanekaragaman dan kelimpahan sumber tanaman inang utama B. carambolae adalah pakan maupun sumber daya lain yang belimbing. Pengamatan di lokasi yang lebih rendah (15 m dpl) banyak ditemukan tanaman papaya dan lokasi pengamatan yang lebih tinggi (568-1167 m dpl) banyak ditemukan tanaman belimbing.

B. albistrigata merupakan salah satu genus Bactrocera yang tanaman inangnya meliputi jambu biji, jambu air, nangka dan jambu bol ( Siwi, 2006). Hasil pengamatan B. albistrigata hanya ditemukan di lokasi pengamatan di Desa Musi Kabupaten Buleleng, hal tersebut diduga karena banyak tersedia pada habitat tersebut.

Kelimpahan populasi lalat buah di alam tidak hanya dipengaruhi oleh faktor intrinsik lalat buah, namun juga dipengaruhi oleh faktor lingkungan meliputi suhu, kelembaban, cahaya, curah hujan, tanaman inang dan musuh alami. Faktor iklim berpengaruh terhadap pemecaran, perkembangan, daya tahan hidup, perilaku, reproduksi, dinamika populasi dan peledakan hama (McPheron dan Steck, 1996 dikutip oleh Astriyani, 2014). 


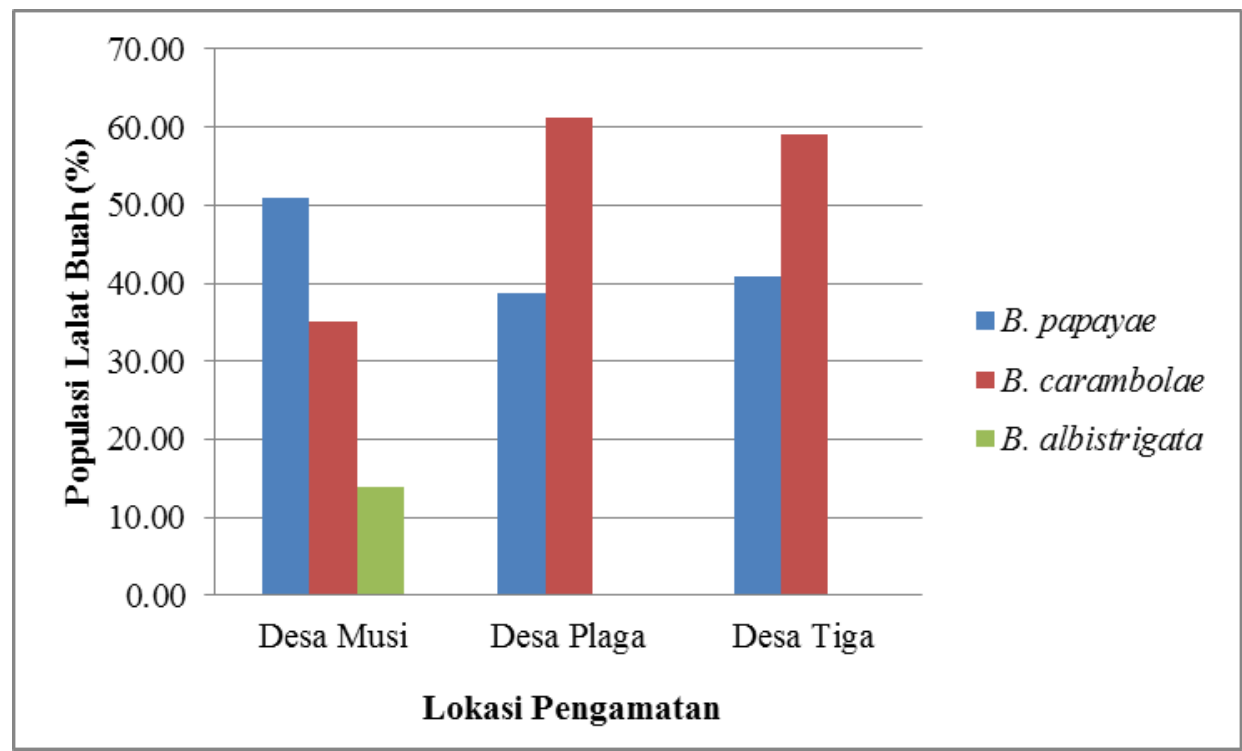

Gambar 4. Kelimpahan Lalat Buah yang Menyerang Jambu Biji Kristal di Bali

\section{Persentase Serangan Lalat Buah}

Serangan lalat buah tertinggi terjadi di Desa Musi Kabupaten Buleleng dengan persentase serangan $(28,62 \%)$, di Desa Plaga Kabupaten Badung $(24,37 \%)$ dan di Desa Tiga Kabupaten Bangli (19,83\%) (Gambar $5)$.

Tinggi rendahnya persentase serangan lalat buah pada tanaman jambu biji sangat dipengaruhi oleh kelimpahan lalat buah. Banyaknya populasi lalat buah juga disebabkan oleh ketersediaan inang yang melimpah di lapang. Data menunjukan persentase serangan tertinggi terjadi di Desa Musi Kabupaten Buleleng hal tersebut disebabkan karena kelimpahan lalat buah disana tinggi dibandingkan dengan lokasi yang lain. Hal tersebut sesuai dengan pernyataan dari Sunarno dan Popoko (2013) bahwa kelimpahan populasi lalat buah sangat erat hubungannya dengan kelimpahan tanaman inang di lapang. Menurut Astriyani et al. (2016) terdapat korelasi yang kuat antara persentase serangan dengan kelimpahan populasi lalat buah. Apabila kelimpahan lalat buah tinggi, maka persentase serangannya juga tinggi, begitu juga sebaliknya.

Persentase serangan juga dapat dipengaruhi oleh teknik pengendalian serangga hama meliputi penggunaan perangkap, sanitasi dan penggunaan pestisida (Vijaysegran dan Osman, 1991 dikutip oleh Putra 2018). Seperti yang diketahui, tanaman jambu biji kristal merupakan komoditas hortikultura yang memiliki nilai ekonomi 
I WAYAN DEDI ADNYANA. et al. Asosiasi Lalat Buah (Bactrocera spp.) (Diptera : Tephritidae)...

tinggi sehingga dibudidayakan dengan teknik pengendalian seperti penyemprotan pestisida dan sanitasi yang mempengaruhi jumlah populasi lalat buah. Pengendalian lalat buah di lokasi pengamatan Desa Musi Kabupaten Buleleng dilakukan dengan penyungkupan buah menggunakan plastik dan kertas koran. Pengendalian lalat buah di Desa Pelaga
Kabupaten Badung dilakukan dengan penggunaan pestisida dan penyungkupan buah menggunakan plastik. Pengendalian di lokasi pengamatan Desa Tiga Kabupaten Bangli hampir sama dengan di lokasi Desa Pelaga namun pengendalian dilakukan lebih intensif.

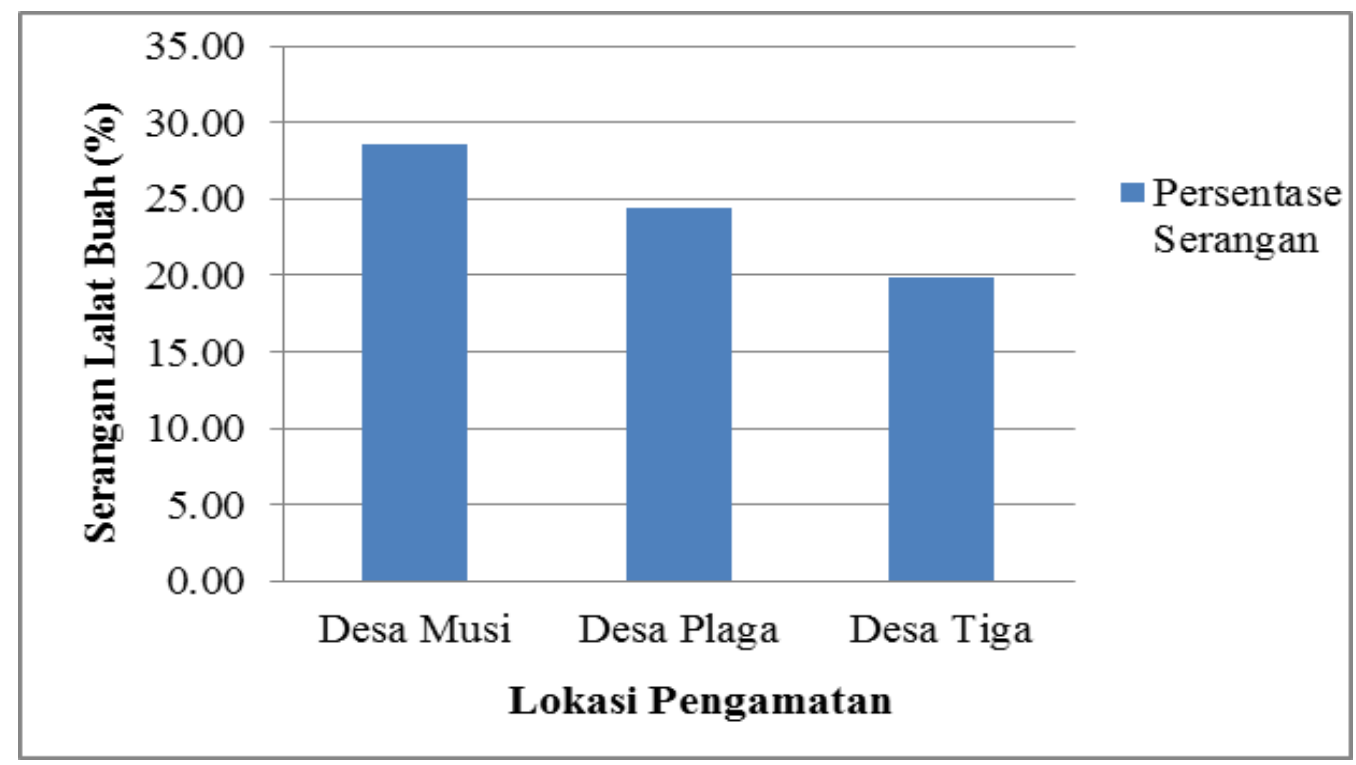

Gambar 5. Persentase Serangan Lalat Buah pada Tanaman Jambu Biji Kristal yang Dibudidayakan di Bali

Jenis Parasitoid yang Berasosiasi dengan Famili Braconidae yaitu Fopius arisanus, Lalat Buah pada Tanaman Jambu Biji Diachasmimorpha sp. dan Opius sp.

\section{Kristal di Bali}

Ditemukan tiga jenis parasitoid yang berasosiasi dengan lalat buah pada tanaman jambu biji kristal di Bali. Ketiga parasitoid tersebut berasal dari Ordo Hymenoptera,
Fopius arisanus (Gambar 6) memiliki ukuran tubuh relatif kecil dengan panjang sekitar 1,6-2 mm, panjang antena 3-3,3 mm. Tubuh berwarna coklat gelap hingga hitam dan memiliki ovipositor yang panjang. Caput berwarna oranye gelap dengan garis hitam 
membujur. Bagian mesonotum berbentuk bulat dengan struktur yang halus. Pangkal antenna berwarna kuning sedangkan antena berwarna kuning kecoklatan. Abdomen berwarna hitam.

Diachasmimorpha sp. ( Gambar 7) memiliki ukuran tubuh yang cukup besar yaitu 3-4 $\mathrm{mm}$. Tubuh berwarna oranye terang. Mesonotum terdiri dari tiga benjolan yang terlihat sangat jelas. Abdomen bagian tergum ke- I dan ke-II, terdapat pola garis- garis membujur. Diantara tergum I dan II terdapat satu cekungan ditengah.

Opius sp. (Gambar 8) memiliki ukuran tubuh yang relatif kecil yaitu kurang dari 2 mm. Tubuh berwarna coklat gelap hingga hitam. Caput berwarna coklat kemerahan. Parasitoid ini memiliki pangkal antena berwarna kuning sedangkan antena berwarna kecoklatan. Tungkai berwarna coklat terang sedangkan pada bagian tarsus berwarna kehitaman.

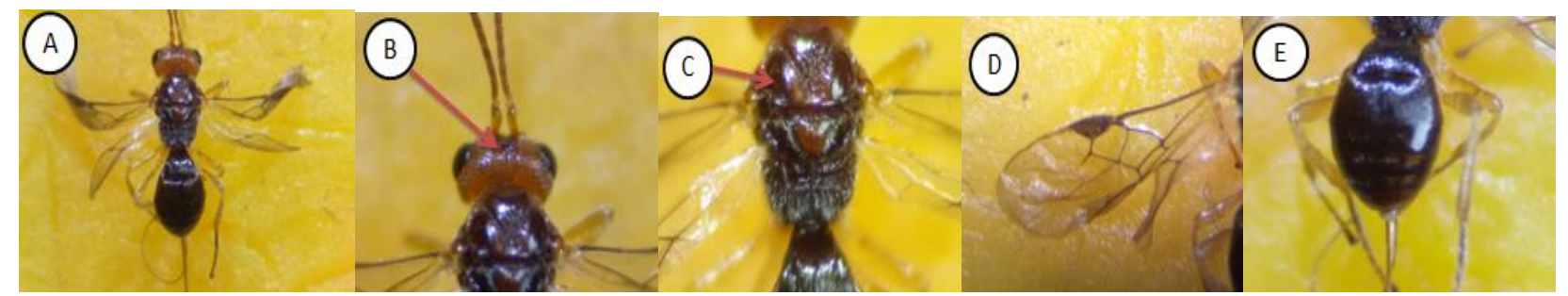

Gambar 6. Karakteristik morfologi Fopius arisanus (A) Keseluruhan tubuh Fopius arisanus (B) Caput : dengan garis hitam membujur pada bagian vertex menuju medial ocelli (C) Torak : mesoscutum berbentuk bulat dengan struktur yang halus (D) Sayap (E) Abdomen : berwarna hitam

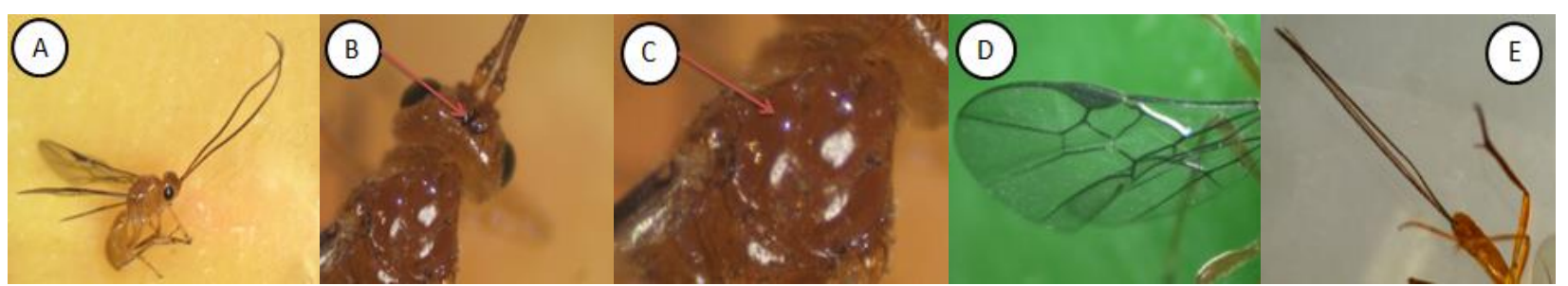

Gambar 7. Karakteristik morfologi Diachasmimorpha sp. (A) Keseluruhan tubuh Diachasmimorpha sp. (B) Caput : terdapat ocelli (C) Torak : Mesonotum terdiri dari tiga benjolan yang sangat jelas (D) Sayap (E) Ovipositor 
I WAYAN DEDI ADNYANA. et al. Asosiasi Lalat Buah (Bactrocera spp.) (Diptera : Tephritidae)...

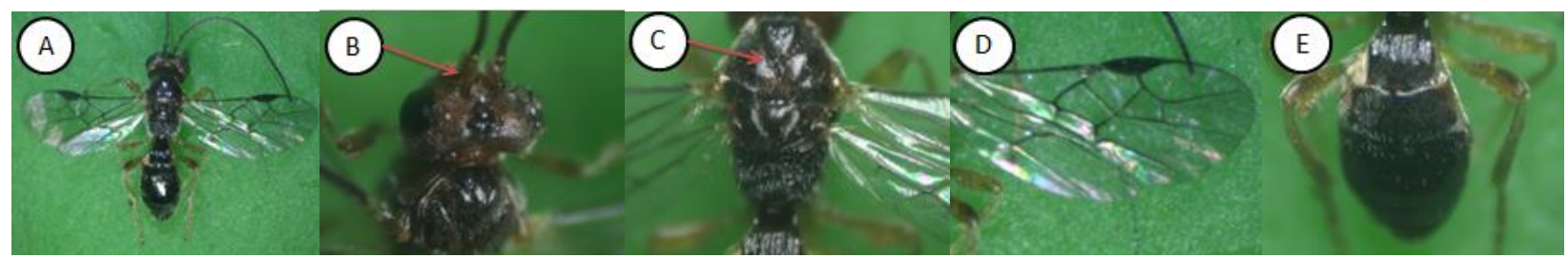

Gambar 8. Karakteristik morfologi Opius sp. (A) Keseluruhan tubuh Opius sp. (B) Caput : pangkal antenna berwarna kuning sedangkan antenna berwarna kecoklatan (C) Torak : bagian mesoskutum terdiri dari tiga benjolan (D) Sayap (E) Abdomen : berwarna hitam

Tingkat Parasitisasi Parasitoid

Hasil penelitian menunjukkan tingkat parasitisasi parasitoid di Desa Musi yaitu Fopius arisanus sebesar (4,17\% ; 216 imago) Opius sp. sebesar $(2,76 \%$; 143 imago) dan Diachasmimorpha sp. sebesar $(1,96 \% ; 104$ imago). Pengamatan di Desa Pelaga yaitu Fopius arisanus sebesar (3,39\% ; 163 imago) Opius sp. sebesar $(1,67 \% ; 78$ imago) dan Diachasmimorpha sp. sebesar $(1,11 \% \quad 52$ imago). Pengamatan di Desa Tiga tingkat parasitisasi Fopius arisanus sebesar $(2,63 \%$; 104 imago), Opius sp. sebesar $(1,53 \% ; 61$ imago) dan Diachasmimorpha sp. sebesar $(1,05 \%$; 42 imago). Rata-rata tingkat parasitisasi parasitoid di Desa Musi yaitu 8,89 $\%$, di Desa Pelaga yaitu 6,18 \% dan di Desa Tiga yaitu 5,20 \% (Gambar 9).

Wiratama (2010) menyatakan bahwa populasi lalat buah di lahan berbanding lurus dengan populasi parasitoid, apabila jumlah lalat buah meningkat maka jumlah parasitoid pun ikut meningkat begitu juga sebaliknya jika jumlah lalat buah menurun maka jumlah parasitoid akan menurun. Berdasarkan hasil analisis tingkat parasitisasi tertinggi terjadi di lokasi Desa Musi, hal ini dapat disebabkan karena kelimpahan populasi lalat buah di lokasi tersebut lebih tinggi dibandingkan dengan lokasi pengamatan yang lain.

Rendahnya populasi parasitoid pada lokasi di Desa Pelaga Kabupaten Badung dan di Desa Tiga Kabupaten Bangli kemungkinan disebabkan oleh pengendalian lalat buah dilakukan dengan penyiangan dan menggunakan pestisida yang lebih intensif. Penggunaan insektisida sintetik yang kurang bijaksana juga dapat mempengaruhi populasi organisme bukan sasaran seperti parasitoid, oleh karena itu populasinya bisa menurun (Apriliyanto dan Setiawan 2016). 


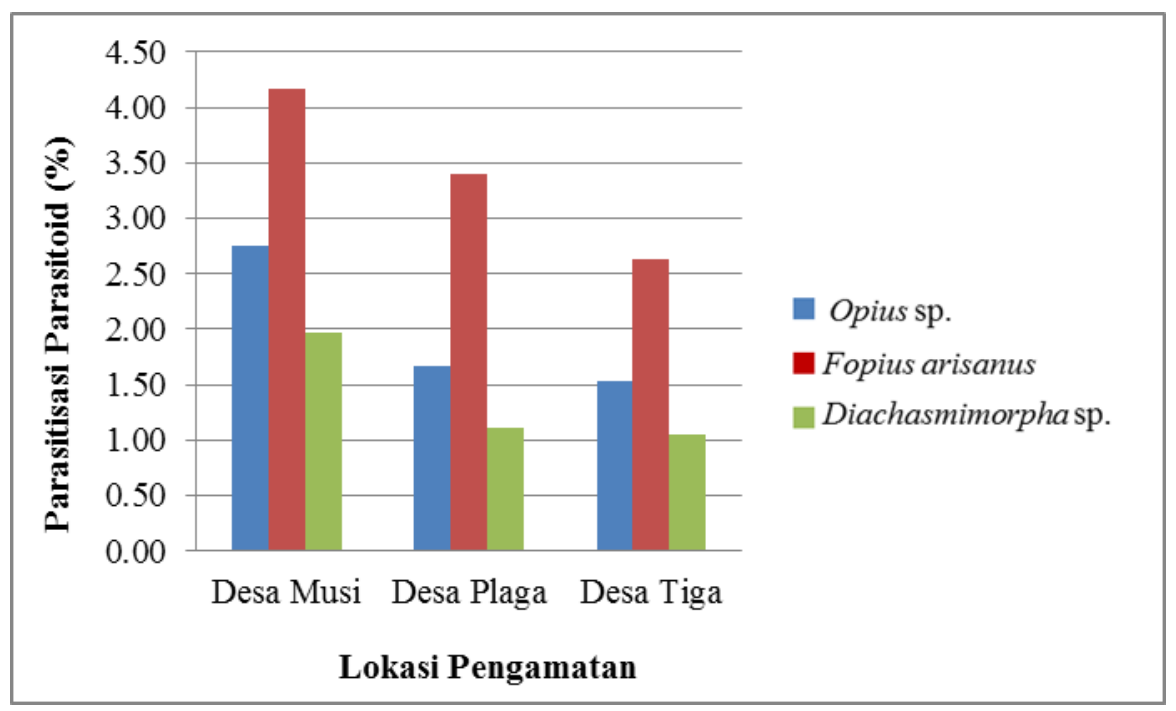

Gambar 9.Tingkat Parasitisasi Lalat Buah pada Tanaman Jambu Biji Kristal di Bali

\section{SIMPULAN}

1. Spesies lalat buah yang menyerang buah jambu biji kristal yang dibudidayakan di Bali ada tiga spesies yaitu carambolae,

$B$. papayae dan $B$. albistrigata. Kelimpahan lalat buah pada tanaman jambu biji kristal di dataran rendah (16 m dpl) didominasi oleh $B$. papayae, sedangkan pada dataran sedang (568 mdpl) dan tinggi $(1167 \quad \mathrm{~m} \quad \mathrm{dpl})$ didominasi oleh $B$. carambolae

2. Persentase serangan lalat buah pada buah jambu biji kristal yang dibudidayakan di Bali rata-rata $24,27 \%$.

3. Spesies parasitoid yang berasosiasi dengan lalat buah pada tanaman jambu biji kristal yang dibudidayakan di Bali ada tiga spesies yaitu, Diachasmimorpha sp., Opius sp. dan Fopius arisanus. Fopius arisanus memiliki populasi tertinggi di bandingkan dengan parasitoid lainnya. Tingkat parasitisasi parasitoid lalat buah pada tanaman jambu biji kristal di Bali rata-rata $6,76 \%$.

\section{. DAFTAR PUSTAKA}

Astriyani, N. K. N. K., Supartha, I. W. dan Sudiarta, I. P. 2016. Kelimpahan Populasi dan Persentase Serangan Lalat Buah yang Menyerang Tanaman BuahBuahan Di Bali. Journal of Agricultural Science and Biotechnology, 5(1), 19-27

Apriliyanto E, Setiawan BH. 2016. Populasi Lalat Buah (Bactrocera spp.) dan Parasitoidnya pada Pertanaman Cabai di Banjarnegara. Media Agrosains. 2(1): 11-15.

Buchori, D., A Meilin, P. Hidayat dan B. Sahari. 2010. Species Distribution of Trichogramma and Trichogrammatoidea Genus (Trichogrammatoidea: Hymenoptera) in Java. J.ISSAAS 16(1): 83-96. Carmichael, Amy C. \& Wharton, Robert A. And Clarke, Anthony R.. 2005. Opiine (Hymenoptera: Braconidae) Parasitoids of Tropical Fruit Flies (Diptera: Tephritidae) of the Australian an South Pasific Region. Bulletin of 
I WAYAN DEDI ADNYANA. et al. Asosiasi Lalat Buah (Bactrocera spp.) (Diptera : Tephritidae)...

Entomological Research 95(6):pp. 545569.

Dinas Pertanian Tanaman Pangan dan Hortikultura. 2014. Produksi Jambu Biji Kabupaten/Kota di Provinsi Bali Tahun 2009-2013

Drew, D. 2011. The Australian Handbook for the Identification of Fruit Flies. Plant Health Australia, 1, 1-214

Hasyim, A., Sudarmo dan Nurhadi., M. Agus. 2008. Identifikasi, Status dan Pengelolaan Lalat Buah di Indonesia. Badan Penelitian dan Pengembangan Pertanian (BPTP). Surabaya. 63 hal

Herlinda. S., Zuroaidah, Y. Pujiastuti, S. Samad, dan T. Adam. 2007. Spesies Lalat Buah yang Menyerang Sayuran Solanaceae dan Cucurbitaceae di Sumatera Selatan. J. Hort. 18(2):212220. Hidayat N. 1982. Pestisida dan Kegunaannya. Armico. Bandung

Hidayat N. 1982. Pestisida dan Kegunaannya. Armico. Bandung.

International Centere for the Management of Pest Fruit Flies (ICMPFF) dan Kementrian Pertanian Republik Indonesia. 2006. Traninig Workshop on Fruit Flies of Indonesia : Their Identification and Pest Status. AQIS Training Facility, Darwin, Australia

Maramis, R. 2005. Kontribusi dari Berbagai Spesies Parasitoid Generalis yang Berasal dari Serangga Inang Erionata thrax L. (Diptera: Tephritidae) pada Habitatnya. Departemen Biologi ITB. Bandung

Mcpheron B, Steck GJ, editor 1996. Fruit Fly Pests. A World Assessment of Their Biology and Management. St. Luice Press (US):Florida.

Putra, I. N. W., I. W. Susila., I. G. N. Bagus., 2018. Kelimpahan Spesies Lalat Buah (Diptera : Tephritidae) dan Parasitoidnya yang Berasosiasi pada Tanaman Belimbing (Averrhoa carambola L.) di Kabupaten Gianyar. Fakultas Pertanian Universitas Udayana. Denpasar

Prihatman, K. 2000. Jambu Biji/Jambu Batu (Psidium guajava L.) . Kantor Deputi Menegristek Bidang Pendayagunaan dan Pemasyarakatan Ilmu Pengetahuan dan Teknologi, Jakarta.

Rai, I N., G. Wijana, I P. Sudana, I W. Wiraatmaja dan C. G. A. Semarajaya. 2016. Buah-Buahan Lokal Bali. Denpasar. Pelawa Sari. $280 \mathrm{Hlm}$.

Sharkey, M. 1. 1992. Clasdistics and Tribal Classification of the Agathidinae (Hymenoptera: Braconidae). Journal of Natural History 26:425-447

Siwi, S.S., P., Hidayat, dan Suputa. 2006. Taksonomi dan Bioekologi Lalat Buah Penting di Indonesia (Diptera : Tephritidae). Balai Besar Penelitian dan Pengembangan Bioteknologi dan Sumber Daya Genetik Pertanian, Bogor.

Sodiq M. 2004. Kehidupan Lalat Buah pada Tanaman Sayuran dan Buah-buahan. Di dalam: Sodiq M, editor. Prosiding Lokakarya Masalah Kritis Pengendalian Layu Pisang, Nematoda Sista Kuning pada Kentang dan Lalat Buah; 2004 Jun 14-16; Jakarta, Indonesia. Jakarta (ID): Pusat Penelitian dan Pengembangan Hortikultura. hlm 13-20.

Trubus. 2014. Jambu Kristal. Jakarta (ID): Trubus.

Vijaysegaran, S. dan M. S. Osman. 1991. Fruit Fly in Penisular Malaysia, Their Economic Importance and Control Strategies. In Chua, T.H. and S.G. Khoo (Eds.). Problem and Management of Tropical Fruit Flies. Proceeding of the International Symposium the Biology and Control of Fruit Flies.Jointly Organized by the Food and Fertilizer of Technology Center The University of The Ryukyus. The 
AGROTROP, 9 (2): 97 - 111 (2019)

Okinawa Prepectural Government: 137140

White, I.M., and E.M. Harris. 1992. Fruit Flies of Economic Significance: Their Identification and Bionomics. Wallingford, UK: CAB Internation

Wiratama, M. D., I. W. Susila dan I. W. Supartha. 2017. Kelimpahan Spesies Lalat Buah (Bactrocera spp.) dan Tingkat Parasitisasi Parasitoid di Sentra Pertanaman Jeruk Provinsi Bali. Fakultas Pertanian Universitas Udayana. Denpasar 